\title{
Editorial
}

\section{Sustainable Welfare beyond Growth}

\author{
Tuuli Hirvilammi ${ }^{1}\left[\right.$ and Max Koch ${ }^{2, *}$ \\ 1 Faculty of Social Sciences, Tampere University, 33100 Tampere, Finland; tuuli.hirvilammi@tuni.fi \\ 2 Socialhögskolan, Lund University, Box 23, 22100 Lund, Sweden \\ * Correspondence: max.koch@soch.lu.se
}

Received: 25 February 2020; Accepted: 26 February 2020; Published: 28 February 2020

\section{Growth-Dependent Welfare States}

The history of welfare states is tightly linked to industrial capitalism and a mode of regulation where production and consumption patterns increased in parallel. This has gone hand in hand with a modernization trend towards extending citizenship rights and a fossil energy regime that provided affordable fossil energy based on unequal exchange patterns between the rich and poor countries. Welfare states as we know them, have been dependent on an expansionary economic model, that is economic growth measured in gross domestic product (GDP), which created the expectation of steadily rising material living standards on the part of citizens [1]. Welfare institutions and social policies have alleviated social risks and fixed market failures but also benefited capitalist accumulation and legitimated the growth-paradigm [2]. Especially the ways in which Nordic welfare states managed to combine comprehensive social security with economic growth have often been praised as success story. The Nordic experience also indicates the significance of partisan politics. Here, the construction of welfare institutions was connected with powerful social democratic parties, which convincingly argued that generous welfare states are capable of delivering greater equality within capitalism [3]. Social policies became legitimate through the belief that extensive social services for child and elderly care, universal social security, and education are social investments that also benefit economic growth [4].

Despite a growing awareness of environmental limits to growth and critiques of GDP as a proxy of wellbeing, European welfare states usually apply growth-oriented policies. During the most recent era of neoliberalism, welfare institutions became modified "to serve new competition-state functions" [5] (p. 18). Social policy became designed to support productivity and adjusted to the needs of competing actors in the global economy. Examples for this include various activation policies and the increasing conditionality and individualization of social benefits. However, the new "supply-oriented" growth strategy largely failed to consider the urgency of the environmental crisis, even though the impacts of climate change and climate mitigation policies as well as other environmental threats has already begun to upset welfare states and other policy domains [6] (p. 113).

The official policy response to the environmental crisis by the Organization of Economic Cooperation and Development, the World Bank, the United Nations Environment Programme as well as the EU and its Member States is 'green growth' and/or 'ecological modernization': the attempt to combine continued GDP growth with a reduction in energy and matter throughput as well as carbon emissions. By reducing energy and material consumption and the rich countries' dependency on the fragile geopolitics of energy supply, providing jobs in the expanding 'green' sector and meeting carbon emission reduction targets, the intention is to achieve synergies between economic, ecological, and also social welfare goals. Central to any evaluation of the feasibility of green growth strategies is the distinction between 'absolute' and 'relative' decoupling of GDP growth from carbon emissions and resource use. While resource usage has declined relative to GDP in a number of developed countries, they have either not done so in absolute terms at all or not to the extent needed to allow the Paris targets to be met $[7,8]$. Not only have improvements in energy efficiency in recent decades been offset 
by increases in the overall scale of economic activity, but the prospects for further improving energy efficiency in the future to the required extent are minimal. Comparative research $[9,10]$ continues to indicate a strong link between the level of economic development measured in GDP per capita, on the one hand, and carbon emissions and ecological production and consumption footprints, on the other.

Not least due to the lack of evidence for absolute decoupling of GDP growth, material resource use, and carbon emissions, an alternative scenario has been tabled: that of 'post-' or 'degrowth' [11]. All growth-critical perspectives have the common starting point that the ecological crisis and the increase in social inequality are basic features of high-consumption capitalism and its spread from North America and Europe to the rest of the world. The common goal is thus to re-embed production and consumption patterns into planetary limits through a decrease in material and energy throughputs, particularly in rich countries. However, if critical amounts of exclusion and anomy are to be prevented during this transition, this will presuppose a more or less parallel transition of a range of social institutions at roughly the same speed and various scales (local, national, global) that are currently in different ways tied to economic growth-a 'great transformation' for which there are few or no historical precedents under democratic circumstances [12].

While degrowth and postgrowth approaches in general have to grapple with the corresponding complexity problem, this Special Issue particularly addresses the intersection of the environmental and welfare systems. Hence, it aims to contribute towards reducing the complexity associated with a degrowth transition. We develop further the concept of 'sustainable welfare', which has generally been conceptualized in terms of satisfying human needs within planetary boundaries. Given the lack of evidence for an absolute decoupling of GDP from matter and energy consumption, we are interested in understanding how welfare systems that are less dependent on economic growth can work and be more focused on achieving integrated sustainability goals than currently.

\section{Sustainable Welfare}

'Sustainable welfare' originates from and continues the 'green' criticism of welfare states from the 1970s. Inspired by, for example, the books edited by Tony Fitzpatrick and Michael Cahill [13-16] and the publications by Ian Gough $[6,17,18]$, research on the intersection of social policy, welfare states, and environmental issues increased over the last 20 years. According to Fitzpatrick and Cahill [13], the green critique of contemporary welfare states addresses the following three points: the status of economic growth as an unquestionable 'meta-ideology', the heavy dependence on employment, and the centralization of control over individuals and communities by and in the national state. According to these critiques, welfare systems should instead be seen as embedded in ecosystems and in need of respecting the regeneration capacity of the biosphere. Subsequently, by using and developing multiple concepts that share similar efforts to integrate ecological and social issues, a range of research on environment and welfare was published under various headings: 'ecosocial welfare' [19], 'sustainable welfare' [17,20], 'eco-social state' [21], 'ecosocial policy' [6,22], and 'sustainable wellbeing' [6,22]. Though these approaches differ in many aspects, they nevertheless share the common ambition to develop welfare concepts and policies that consider the environmental crisis and/or the limits to growth. This collection uses 'sustainable welfare' as an umbrella term to address the intersection of social and environmental goals and policies.

That linking welfare and the environment is necessary is illustrated by the fact that ambitious climate policies have distributional repercussions, which threaten to make them unpopular with electorates. These distributional effects have been addressed in theories of climate justice and in models of burden sharing between rich and poor countries [23]. Yet even within the rich countries such effects question the feasibility of decarbonization strategies in economically advanced democratic societies. Different societal groups have different responsibilities for fighting climate change, and experience different impacts. Responsibilities and impacts often work in opposing ways, constituting a 'double injustice' [24], since the groups likely to be affected most by climate change are the ones least responsible for causing it. If rich countries and, within the rich countries, richer households continue 
to pay less than what climate expertise regards as necessary, this may even turn into a 'triple injustice', since the poor are the least able to bear the financial burden of climate policies [6]. For example, low-income households spend a relatively high proportion of their income on energy-intensive needs such as heating and/or cooling and would thus be hardest hit by a general rise in energy prices [25].

Social policies will need to address the inequalities and conflicts that are likely to emerge as a result of the decarbonization of production and consumption patterns, and it will be increasingly necessary to formulate them in ways that create synergies with environmental goals, yet are also acceptable to the electorate. 'Sustainable welfare' recognizes the long-term implications of contemporary production and consumption patterns, and, accordingly, raises normative questions such as whose welfare should be represented in current welfare societies. Brandstedt and Emmelin [26] argue that the distributive principles underlying existing welfare systems would need to be extended to include those affected in other countries and in the future. Current welfare provision would need to consider that satisfying present welfare demands should not undermine the ability of future generations to meet their welfare needs. This includes the recognition of critical thresholds and limitations, and also of the fact that needs, aspirations, and wants must be reviewed-and possibly restrained. Hence, the understanding of climate change as a devastating threat, in particular, and the very idea of environmental sustainability, in general, constitute a challenge to 'business as usual' in social policy and have significant implications for the scope and direction of welfare policies, which would need to give greater weight to distribution and justice across nations and generations. Within the concept of 'sustainable welfare' (and indeed in degrowth), the key welfare concern is not the provision and distribution of material riches to the 'happy few' in Western societies, but rather the satisfaction of basic needs for all humans now and in the future [27,28].

Despite the necessity to link social welfare and climate policies-and the above mentioned exceptions in the social policy literature-there has been a lack of theorizing on their intersection, with scholars tending to conduct research within the two areas without much cross-fertilization. Much current welfare literature focuses on the crisis of post-war welfare state arrangements and on the readjustments and recalibrations following the 2008 financial and economic crisis [29,30], while environmental concerns, raised as early as the 1970s, remain largely ignored [31]. In fact, within the social policy literature, the concept of sustainability refers mainly to the challenges of 'fiscal' or 'economic' [32] as well as 'social' sustainability. Conversely, the environmental sustainability literature has not paid much attention to welfare issues. However, this would be necessary as ambitious climate policy targets have, as mentioned above, distributional consequences that threaten to make them unpopular amongst voters. Much points to the temporary conclusion that any 'just' transformation is feasible only to the extent that social and environmental policies are implemented together in an integrated and intentional manner.

A growing body of literature argues that welfare policies qualitatively different from those that emerged in the post-World War II context will be necessary to counteract the distributional consequences of ambitious climate policy targets such as those set forth in the 2015 Paris Agreement. An alternative eco-welfare governance network would need to redistribute not only carbon emissions, but also work, time, income, and wealth. Policy alternatives have hitherto been developed in diverse research fields, that is, in isolation and without clear connections to each other. As a corollary, a systemic and encompassing understanding of sustainable welfare policies is still missing.

\section{The Contributions to the Special Issue}

In asking what it requires to make welfare states ecologically sustainable, this Special Issue regards the current financial, economic, and political crisis and the corresponding adjustments in existing welfare state institutions as an impetus to also consider the environmental crisis and reach beyond the growth imperative. We invited papers that seek to develop theoretical perspectives on welfare and wellbeing within environmental limits, to provide empirical studies that combine sustainability and welfare perspectives, and to discuss (emerging) eco-social policies for sustainable 
welfare beyond growth. The collection covers all these aims with a wide range of both theoretical and empirical approaches. More particularly, the contributions to this Special Issue relate to three themes: (1) emerging signs of eco-social policy integration, (2) public support for sustainable welfare, and (3) transforming welfare policies.

\subsection{Emerging Signs of Eco-Social Policy Integration}

Katharina Zimmermann and Paolo Graziano use a Eurostate and EPI-Database to contrast environmental and social performances in 27 European countries in order to find links between the social and ecological realms. They discuss decommodification processes in social and environmental policies and ask whether the interactions of social and environmental outcomes and performances follow country cluster lines. A hierarchical cluster analysis results in six different clusters. A further analysis of various performance indicators (e.g., environmental health, Gini, and unemployment) reveals differences between clusters in terms of their performance in social and ecological dimensions. The third step of the analysis includes structural indicators (e.g., the GDP, the ratio of fossil to renewable energy consumption, and union density) that are used to determine how certain economic, political, and policy-related aspects matter in shaping "worlds of eco-welfare states". The results show specific configurations of eco-social performance. For example, the Nordic countries perform relatively well on both dimensions whereas southern welfare states perform better in ecological than in social dimension. However, the clusters overlap only partly with more conventional ideas of welfare regimes or "worlds of welfare states". The article points towards a need to develop quantitative datasets and qualitative research settings to better understand "the conditions and the mechanisms" of (better) "eco-social performances".

Jamil Khan, Rober Hildingsson, and Lisa Garting study the integration of ecological sustainability and social welfare at the urban level. Are there signs of an 'eco-social integration' or an emerging sustainable welfare agenda in Sweden? Analyzing policy documents and interview data collected in Malmö, Gothenburg, and Stockholm, the authors ask whether the ecological and social issues are dealt with in isolation or an integrated manner. The findings show that even though both environmental and social issues are relatively high on political agendas, they are mostly managed as quite separate topics. Connections are acknowledged but usually not addressed in any systemic way. Any eco-social policy integration remains to be a rather marginalized issue and takes place mainly in an ad hoc fashion or in short-term projects. The interest in eco-social policy integration has recently increased due to Agenda 2030 and climate change mitigation but is visible mainly at a rhetorical and conceptual level. Finally, the authors find that an eco-social integration in the three cities relates mainly to local and tangible issues such as urban gardening or access to green areas rather than to global concerns that are often emphasized in sustainable welfare theory.

Jana Brandl and Irina Zielinska argue that policies towards a socio-ecological transformation should focus more on work and the quality of work than previously. Research on sustainable welfare and degrowth has as yet not systematically addressed issues of the quality of work: income, work-related health implications, work design, qualifications, and job satisfaction. The article is developed through a review of the Smart City Vienna Framework Strategy that aims to integrate environmental, social, and economic issues. By interviewing experts working in the transportation, construction and energy sectors the two authors ask how these informants expect the strategy to impact on the quality of work and how they approach the relationship between environmental issues and the quality of work. They also analyze whether the strategy is related to a 'green economy' paradigm or degrowth paradigm and explain the lack of integrative eco-social policy framework with the embeddedness within the green economy paradigm. Brandl and Zielinska find that the Smart City Vienna framework is based on a narrow understanding of work, which makes it difficult to address the relationship between environmental sustainability and the quality of work. 


\subsection{Public Support for Sustainable Welfare}

Martin Fritz and Max Koch study 'public support for sustainable welfare', specifically the extent to which people who support ambitious climate policies also are in favor of welfare policies and vice versa. The two authors use 2016 European Social Survey data in which respondents from 23 European countries answered questions about their opinions on climate change and welfare policies. The survey included items both on environmental attitudes, particularly the climate, and on perceptions about the welfare state and equality, which allows for an analysis of eco-social issues as they are reflected in people's attitudes and according to socio-demographic and political factors such as class, gender, education, age, or political view. Hence, the article comparatively shows how attitudes towards both welfare and climate policies interact and what kind of socio-demographic and political factors are supportive for eco-social policies. The results of a multiple correspondence analysis indicate, among other things, that the simultaneous support of welfare and climate policies and hence 'sustainable welfare' follows welfare regime lines in that this support is the highest among social-democratic countries. However, also some conservative and Mediterranean countries score high in this regard. At the individual level, people with a higher education, employees in socio-cultural professions, and voters of moderate left and green parties display the highest mutual support for welfare and climate policies. Policy makers could be bolder than currently in their attempts to form political coalitions around an eco-social policy strategy.

The starting point for Adeline Otto and Dimitri Gugushvili is the notion that the public support bases for social and environmental policies are different which might deepen existing social divides. Like Fritz and Koch, they study public attitudes based on European Social Survey 8 data. Unlike previous research, which measured the correlation between welfare and environmental attitudes, the authors hypothesize four ideational groups: eco-social public policy enthusiasts, welfare enthusiasts, environment devotees, and eco-social public policy sceptics. The descriptive statistics indicate that Europeans are almost evenly divided into these four ideational groups. The analysis also shows that the group displaying 'eco-social enthusiasm' is largest in the Nordic countries and that woman are less often eco-social sceptics than men. Furthermore, individuals in secure financial situations are likely to be eco-social enthusiasts. In addition, through an examination of contextual variables, the article points out that higher GDP per capita is related to lower levels of eco-social and welfare enthusiasm. This finding may support the argument that people in richer countries are "more inclined to suppress the feeling of guilt towards environment through denial". Alternatively, it may reflect the worry "about the costs of transition to more environment-friendly societies". In relation to policymaking, the two authors highlight the importance of investments into education and rural areas where the share of eco-social sceptics is the highest.

Against the background that social movements can change the public and political agendas on climate change via bottom up mobilization, Kajsa Emilsson, Håkan Johansson, and Magnus Wennerhag study contemporary environmental and climate movements, in particular, "Fridays for Future" in Sweden. Inspired by key issues related to Sustainable Welfare beyond Growth, they ask whether "protesters put the 'environment' or 'welfare' first in the views on societal change". They use survey data collected in various demonstrations to analyze the climate protesters' support for three different frames: environmental frame, economic growth-oriented frame, and welfare frame. Explanatory variables include political and ideological orientation (e.g., party identification), movement involvement (membership in organizations), as well as social characteristics (e.g., gender, age, education). The results present interesting variations between different types of protesters. As expected, most protesters share opinions that are rather pro-environment than pro-economy and give the environment priority over economic growth. This is particularly prominent among those who identify with green and radical left parties or who share egalitarian values. However, the choice between support of a welfare or environmental frame turns out to be more complicated. The results point to rather diverse views. Large proportions of respondents could not take a stance towards disagreeing or agreeing with the statements. As the authors write, this may reflect a "more profound puzzle" or "frame dilemma", 
where protesters are confronted with pro-environment and pro-welfare frames that both come with positive connotations. It is also possible that this dilemma refers to the broader ethical questions "whether individuals' welfare needs should be subordinate to the present pressure of climate change" and how egalitarian policies are favored in climate change mitigation.

\subsection{Transforming Welfare Policies}

For the time being, research on transforming sustainable welfare systems has mostly been carried out at a rather abstract and conceptual level, while more nuanced questions of alternative welfare benefit systems remain understudied. Katharina Bohnenberger contributes towards filling this research gap and creates a new framework for sustainable welfare benefits at the example of universal basic vouchers. She presents a typology of sustainable welfare benefits that include: (1) universal basic income (unconditional basic income, transition income), (2) universal basic vouchers (quasi-currency vouchers, needs vouchers, commons-innovations vouchers), and (3) universal basic services (state services, free consumption goods, public infrastructure). After classifying the benefits, the author compares the policy proposals in relation to 'sustainable welfare criteria': whether and how these welfare benefits guarantee needs satisfaction, support social inclusion, respect ecological limits, allow freedom to determine an own lifestyle, promote economic viability and growth independence, and support an eco-social transformation. Bohnenberger concludes that a successful sustainable welfare policy is likely to be a mix of the different benefit types, depending on the area and societal circumstances. The article enables policymakers to extend their toolkit of policy proposals and shows with illustrative examples that alternatives to current social benefits, paid with general-purpose money, actually exist.

Tuuli Hirvilammi approaches the transformation of welfare states from the perspective of historical institutionalism and argues that policy ideas matter when changing policies. She explains how the growth dependence of welfare states has historically been accompanied by the notion of a virtuous circle. This notion turned out to be a powerful policy idea especially in the Nordic welfare states that aimed to legitimate growth while ensuring that social policy measures do not conflict with economic growth. It is based on systemic thinking and connects different institutions and policy goals. The current ecological crisis, however, imposes the need to reframe the policy idea from an ecological perspective. Such reframing is necessary to overcome the current paradox where economic growth is causing risks to human wellbeing, while all welfare systems nevertheless depend on the growth paradigm. The article argues that an eco-social transformation requires a new policy idea: the virtuous circle of sustainable welfare. This circle is based on a regenerative and distributive economy in which policy changes would lead to win-win situations so that social and ecological problems are simultaneously addressed. Hirvilammi emphasizes that the idea of virtuous circle provides a holistic approach to avoid trade-offs and contradictions between social, environmental, and economic policies.

Acknowledgments: Tuuli Hirvilammi's contribution to this paper was supported by The Strategic Research Council (SRC) at the Academy of Finland research project "Towards EcoWelfare State: Orchestrating for Systemic Impact (ORSI)" (grant no. 327161). Max Koch's contribution benefited from funding from the Swedish Energy Agency (Energimyndigheten) project 'Sustainable Welfare for a New Generation of Social Policy' (project no. 48510-1) and from the FORMAS (Swedish Research Council FORMAS) project 'The New Urban Challenge: Models of Sustainable Welfare in Swedish Metropolitan Cities' (grant no. 2016-00340).

Conflicts of Interest: The authors declare no conflict of interest.

\section{References}

1. Gough, I.; Meadowcroft, J. Decarbonizing the Welfare State. In Oxford Handbook of Climate Change and Society, 1st ed.; Dryzek, J., Norgaard, R., Shlossberg, D., Eds.; Oxford University Press: Oxford, UK, 2011; pp. 490-503.

2. Büchs, M.; Koch, M. Postgrowth and Wellbeing. Challenges to Sustainable Welfare, 1st ed.; Palgrave: Cham, Switzerland, 2017.

3. Pierson, C. Beyond the Welfare State? The New Political Economy of Welfare, 3rd ed.; Polity Press: Cambridge, UK, 2006. 
4. Hirvilammi, T. The Virtuous Circle of Sustainable Welfare as a Transformative Policy Idea. Sustainability 2020, 12, 391. [CrossRef]

5. Kettunen, P. The transnational construction of national challenges: The ambiguous Nordic model of welfare and competitiveness. In Beyond Welfare State Models: Transnational Historical Perspectives on Social Policy, 1st ed.; Kettunen, P., Petersen, K., Eds.; Edward Elgar: Cheltenham, UK, 2011; pp. 16-40.

6. Gough, I. Heat, Greed and Human Need: Climate Change, Capitalism and Sustainable Wellbeing, 1st ed.; Edward Elgar: Cheltenham, UK, 2017.

7. Antal, M.; Van Den Bergh, J. Green growth and climate change: Conceptual and empirical considerations. Climat. Polic. 2014, 16, 165-177. [CrossRef]

8. Hickel, J.; Kallis, G. Is green growth possible? New Polit. Econ. 2019. [CrossRef]

9. Fritz, M.; Koch, M. Economic Development and Prosperity Patterns around the World: Structural Challenges for a Global Steady-State Economy. Glob. Environ. Chang. 2016, 38, 41-48. [CrossRef]

10. O'Neill, D.; Fanning, A.; Lamb, W.; Steinberger, J. A good life for all within planetary boundaries. Nat. Sustain. 2018, 1, 88-95. [CrossRef]

11. Khan, J.; Clark, E. Green political economy: Policies for and obstacles to sustainable welfare. In Sustainability and the Political Economy of Welfare, 1st ed.; Koch, M., Mont, O., Eds.; Routledge: London, UK, 2016; pp. 77-93.

12. Büchs, M.; Koch, M. Challenges to the Degrowth Transition: The Debate about Wellbeing. Futures 2019, 105, 155-165. [CrossRef]

13. Fitzpatrick, T.; Cahill, M. (Eds.) Environment and Welfare: Towards a Green Social Policy; Palgrave Macmillan: Hampshire, NY, USA, 2002.

14. Cahill, M.; Fitzpatrick, T. (Eds.) Environmental Issues and Social Welfare; Blackwell: Oxford, UK, 2002.

15. Cahill, M. The Environment and Social Policy; Routledge: London, UK, 2002.

16. Fitzpatrick, T. (Ed.) International Handbook on Social Policy and the Environment; Edward Elgar Publishing: Cheltenhamn, UK, 2014.

17. Gough, I. Climate change and sustainable welfare: The centrality of human needs. Camb. J. Econ. 2015, 39, 1191-1214. [CrossRef]

18. Gough, I. Welfare states and environmental states: A comparative analysis. Environ. Polit. 2016, $25,24-47$. [CrossRef]

19. Fitzpatrick, T.; Caldwell, C. Towards a Theory of Ecosocial Welfare: Radical Reformism and Local Exchanges and Trading Systems (LETS). Environ. Polit. 2001, 10, 43-67. [CrossRef]

20. Koch, M.; Mont, O. (Eds.) Sustainability and the Political Economy of Welfare; Routledge: London, UK, 2016.

21. Koch, M.; Fritz, M. Building the eco-social state: Do welfare regimes matter? J. Soc. Polic. 2014, 43, 679-703. [CrossRef]

22. Hirvilammi, T.; Helne, T. Changing Paradigms: A Sketch for Sustainable Wellbeing and Ecosocial Policy. Sustainability 2014, 6, 2160-2175. [CrossRef]

23. Roberts, J.; Parks, B. A Climate of Injustice. Global Inequality, North-South Politics, and Climate Policy; MIT Press: Cambridge, MA, USA, 2006.

24. Walker, G. Environmental Justice: Concepts, Evidence and Politics; Routledge: London, UK, 2012.

25. Büchs, M.; Bardsley, N.; Duwe, S. Who bears the brunt? Distributional effects of climate change mitigation policies. Crit. Soc. Polic. 2011, 31, 285-307. [CrossRef]

26. Brandstedt, E.; Emmelin, M. The concept of sustainable welfare. In Sustainability and the Political Economy of Welfare, 1st ed.; Koch, M., Mont, O., Eds.; Routledge: London, UK, 2016; pp. 15-28.

27. Koch, M.; Buch-Hansen, H.; Fritz, M. Shifting priorities in degrowth research: An argument for the centrality of human needs. Ecol. Econ. 2017, 138, 74-81. [CrossRef]

28. Helne, T.; Hirvilammi, T. Having, Doing, Loving, Being: Sustainable Well-Being for a Postgrowth Society. In Towards a Political Economy of Degrowth, 1st ed.; Chertkovskaya, E., Paulsson, A., Barca, S., Eds.; Rowman \& Littlefield: London, UK, 2019; pp. 225-242.

29. Kazepov, Y. (Ed.) Rescaling Social Policies towards Multilevel Governance in Europe; Aldershot: Ashgate, UK, 2010.

30. Hemerijck, A. Changing Welfare States; Oxford University Press: Oxford, UK, 2013. 
31. Schoyen, M.; Hvinden, B. Climate change as a challenge for European welfare states. In Handbook of European Social Policy, 1st ed.; Kenneth, P., Lendvai-Bainton, N., Eds.; Edward Elgar: Cheltenham, UK, 2017; pp. 371-385.

32. Bailey, D. The environmental paradox of the welfare state: The dynamics of sustainability. New Polit. Econ. 2015, 20, 793-811. [CrossRef]

(C) 2020 by the authors. Licensee MDPI, Basel, Switzerland. This article is an open access article distributed under the terms and conditions of the Creative Commons Attribution (CC BY) license (http://creativecommons.org/licenses/by/4.0/). 